\title{
MONITORING OF EATING HABITS AND PHYSICAL ACTIVITY LEVELS AS A BASIS FOR A NEW NONCOMMUNICABLE DISEASE PREVENTION PROGRAMME IN THE REPUBLIC OF MACEDONIA
}

\author{
Vera Simovska-Jarevska*, **, Sasko Martinovski**, Dragan Damjanovski**, \\ Valentina Pavlova**, Daniela Nikolovska-Nedelkoska**, and Gjorgji Manceski *** \\ * Public Health Institutions-Skopje, Institute of Sports Medicine, Nutrition Research Department, \\ Krste Miairkov bb, Skopje 1000, REPUBLIC OF MACEDONIA; \\ vera.simovska@uklo.edu.mk \\ ** University of Bitola "St. Kliment Ohridski", Faculty of Technological and Technical Sciences-Veles, \\ Petre Prlicko 14, Veles 43000, REPUBLIC OF MACEDONIA; \\ ttfv@uklo.edu.mk \\ *** University of Bitola "St. Kliment Ohridski", Faculty of Economy, 4800 Prilep, Djordje Petrov bb, REPUBLIC OF MACEDONIA; \\ gmanceski@gmail.com
}

Communicated by Ingrīda Rumba

\begin{abstract}
Research evidence on health determinants has led to development of a national programme for noncommunicable disease (NCD) prevention. Numerous studies have confirmed the role of nutrition and physical activity in preventing main NCDs: cardiovascular disease, type 2 diabetes, cancer and chronic respiratory disease. The aim of the study was to analyse and evaluate the results obtained from the new "cross-sectional" study in 2012 offer monitoring of eating habits and physical activity levels monitoring related to socioeconomic status of the participants in 2012. The study was conducted in five regions of the Republic of Macedonia and included 1600 respondents aged 10 to 64 years. Monitoring was conducted using self-designed questionnaire. Eating habits were surveyed using questionnaires to monitor the frequency of consumption of main food groups during a week. Leisure time physical activity was a priority measure in the study. Also, in the study a model was applied for strategic planning in NCD prevention, based on the results of the health behaviour survey. The model was analysed using a software package. The results indicate that NCDs prevention through improving physical activity levels and changes in eating habits should be focused on changes in food content including availability of whole grain bread, guidelines and policy on food labelling and health claims, marketing and city planning that facilitates an active life.
\end{abstract}

Key words: NCDs prevention, eating habits, physical activity levels, socioeconomic differences.

\section{INTRODUCTION}

Four major noncommunicable diseases (NCDs) are the greatest public health problem in the WHO European region, with approximately $86 \%$ of all deaths in the region caused by this broad group of diseases that includes cardiovascular disease (CVD), cancer, type 2 diabetes (T2DM) and chronic respiratory disease. Nearly four out of five deaths $(80 \%)$ from NCDs occur in low- or middle income countries. Also, NCDs result in mortality at a younger age in low and middle-income countries - on average, ten years younger than in high-income countries (Anonymous, 2011).

NCDs have multifactorial etiology and they are a result of complex interaction between individual characteristics (gen- der, age, ethnicity, genetic predisposition) together with social, economic and environmental determinants (education, income, living and working condition). They are a consequence of a transition in lifestyles that leads to increased risk of NCDs. The most prominent NCDs are linked to common risk factors: an unhealthy diet and lack of physical activity, tobacco use and harmful use of alcohol. Six of the seven key determinants of mortality in developed countries are related to how we eat, drink and move. Diet and physical activity, together with tobacco and alcohol, are key determinants of contemporary public health. Nutrition is one of the main determinants (Anonymous, 1990).

A large percentage of NCDs can be prevented by reducing the main risk factors. The greatest potential for NCDs pre- 
vention and control lies in population based integrated preventive interventions targeting lifestyle risk factors: diet, physical activity and tobacco (Anonymous, (2008). The study of dietary habits and physical activity levels in the community action programmes both as major health determinants and also as important public health issues for which accurate, reliable and comparable information is needed as a basis for the development of evidence-based strategy and programmes in the field of NCDs prevention. The burden of NCDs is increasing rapidly in the developing world, very much as a result of changes in lifestyles. In addition to changes in tobacco use and physical activity, major changes are taking place in diets, which is contributing greatly to the growing epidemic of NCDs. Thus, a huge global public health challenge is how to influence the trends in diet and nutrition for effective global NCDs prevention.

The Republic of Macedonia needs to address its growing NCDs epidemic through health promoting partnerships, strategies and programmes. High-level political commitment, inter-sectoral coordination, and community mobilisation are important in developing a successful, national, multi-sectoral programme for the prevention and control of NCDs. An efficient multi-sectoral mechanism is also crucial at the stage of monitoring, evaluating enforcement of strategy, and analysing impact of multi-sectoral initiatives on reducing NCDs burden in the country.

Country-level surveillance and monitoring systems, including surveys that are integrated into existing national health information systems and include monitoring exposure to risk factors, outcomes, social and economic determinants of health, and health system responses are needed, recognising that such systems are critical in appropriately addressing NCDs (Puska et al., 1995).

The first Plan of Action for Integrated Community and Primary Care Based Prevention and Control of NCDs as well as the Cancer Prevention Programme of Republic of Macedonia were implemented in years 2002-2005 (Anonymous, 2003).

This paper presents the link between food habits and physical activity levels in socioeconomic groups in the Republic of Macedonia. Disparities in food habits are defined as the differences in food consumption based on education and/or occupation/income in population. Food consumption is measured as frequency of consumption of the following items or groups: fruit and vegetables, milk and dairy products, meat and type of bread (Ross et al., 1999).

We need more scientific knowledge on how socioeconomic differences in eating behaviour and physical activity among the Macedonian population can be explained. To establish the second health-risk behaviour surveillance system is a useful tool to obtain more specific data for strategic planning on regional and local levels related to socioeconomic status of population and regional or local situation in food and nutrition.
This study focuses on individual social determinants, such as education and incomes. It is known that education might provide potential cognitive resources that influence an individual's healthy choices. In addition, educational success may forecast future success: better jobs, higher income, good living area and better housing etc. Assessing how socioeconomic differences in food habits and physical activity levels can be explained, we can more efficiently promote healthier nutrition and physical activity among those with low socioeconomic position in the Republic of Macedonia.

Our hypothesis was that the differences in eating habits and physical activity levels are based on socioeconomic factors such as education, income, occupation/profession, poverty, ethnicity, locality and gender. Socioeconomic status affects the healthiness of the diet.

The general objective of the study was to obtain information and to describe socioeconomic differences in eating habits and physical activity levels.

The specific aims were:

- to analyze and evaluate the results obtained from the new "cross-sectional" study for socioeconomic differences: relationships of educational levels and income with the consumption of the main health-related foods and physical activity levels in the Republic of Macedonia, in 2012;

- to set-up a model that describes how multi-sectoral action can effectively address such challenges through mainstreaming NCDs prevention into national health and development programmes.

\section{MATERIALS AND METHODS}

The new "cross-sectional" population-based study was conducted at the Faculty of Technology and Technical Sciences-Veles at the University St. "Clement of Ohrid" in Bitola. The study was carried out between March and May 2012 in five regions in the Republic of Macedonia, and included 1600 respondents aged 10 to 64 years.

Eating habits were measured as frequencies of consumption of the following food groups: fruit and vegetables, milk and dairy products, meat and type of bread from responses in a food frequency questionnaire (FFQ).

Physical activity levels were measured as leisure time physical activity (LTPA). The questionnaire included a comprehensive list of examples of brisk walking and cycling, known as physical activity with moderate intensity as well as organized sports known as strenuous activity. Leisure time physical activity (LTPA) is a personally chosen activity undertaken in an individual's free time that can be motivated by several reasons, such as health benefits, aesthetics, social contacts and fun. Exercise and sports is a form of LTPA that is more planned, structured and aims at more specific objectives, for example the improvement of physical fitness. 
Several socioeconomic measures were linked from the national population register. Indicators of socioeconomic inequalities in health behaviour, including nutrition and physical activity levels by gender and age groups were education and income. Socioeconomic differences in food groups' consumption and physical activity levels were analysed.

Educational levels were often grouped according to a standard 5-level classification developed by the OECD (Anonymous, 1997). For practical reasons, educational levels were grouped as basic (elementary), secondary and higher education (university degree).

Income was measured as family monthly income divided by the number of family members. Income was grouped in three classes: up to 75 Euros, from 75 to 150 Euros and over 150 Euros per month.

In the study a model was applied for strategic planning for NCD prevention and health promotion using software package for data analyzing (Martinovski, 2012). This model was chosen for two reasons. The first was to show the application of the proposed concept in public health, food technology, nutrition and economy. The second reason was that the Faculty of Technology and Technical Sciences-Veles had been created a database from its current research on the socioeconomic impact on a healthy diet and physical activity level.

The results were presented in percentages (\%) of total numbers of the participants in the study by education and income.

\section{RESULTS}

Eating habits. A considerable part of the health behaviour study dealt with monitoring of food habits in Macedonian population, in 2012 .

Bread. The most remarkable result has observed was regarding the usage of black and whole grain bread; people with better income consumed more frequently black and whole grain bread in comparison with those with low socioeconomic status (Fig. 1).

Also, use of these types of bread was more prevalent among higher educated people (Fig. 2).
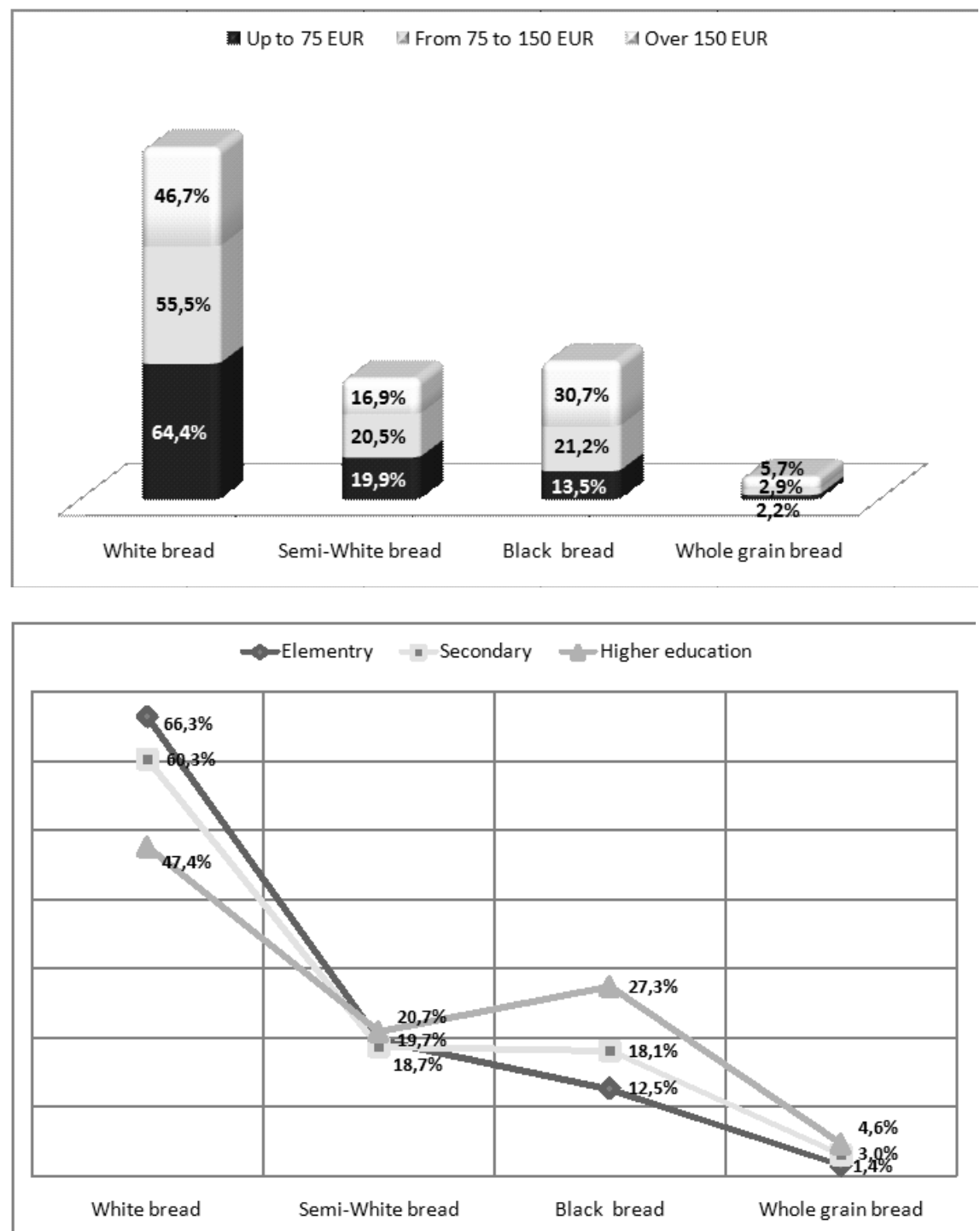

Fig. 1. Proportion (\%) of participants using different type of bread by income in 2012 .

Fig. 2. Proportion (\%) of participants using different type of bread by education levels in 2012 . 
Milk and dairy products. Education and monthly income of the participants had high impact on the frequency of consumption of milk and dairy products.

Less frequently consumption of selected foods in Republic of Macedonia in 2012 were related to lower income and less education (Figs. 3 and 4).

Regarding content of fat in milk and dairy products more frequently low-fat were used by people with higher education.

In general, we noticed less frequent consumption of dairy products that were enriched with vitamins and minerals.

Perhaps, media education regarding food labelling and health claims are needed.

Vegetables and fruit. Education and family monthly income had little impact on the frequency of consumption of fruits and vegetables (Figs. 3 and 4).

The main reason was the relatively low price, availability and relative good production of vegetables and fruits in the Republic of Macedonia.

Meat. Regarding consumption of meat and meat products, most of the study participants consumed more frequently chicken and pork, but less fish. One of the reasons for this is the low price of chicken in the country.
In general, participants with higher education and higher income, more frequently used fish and beef meat.

Physical activity levels. The results showed that monthly income had little impact on physical activity with low intensity such as walking. $35 \%$ of all participants from families with different monthly income walked regularly.

The proportion of sedentary participants who had only lower education was $40 \%$ of all study participants. Physical activity with moderate and higher intensity such as organized sports activities were related to the higher income.

\section{DISCUSSION}

This is the first national "cross-sectional" study in the Republic of Macedonia conducted with the aim to analyse and evaluate data on socioeconomic differences in educational levels and income on the consumption of the main healthrelated foods and physical activity levels of the population (10-64 years).

On the European level, the differences in food consumption in relation to education and income were examined in an adult population (18-65 years) in 1985-1997 as part of the FAIR-97-3096 project "Compatibility of The Household and Individual Nutrition Survey in Europe and Disparities in Food Habits" (Roos et al., 1999). Forty seven studies
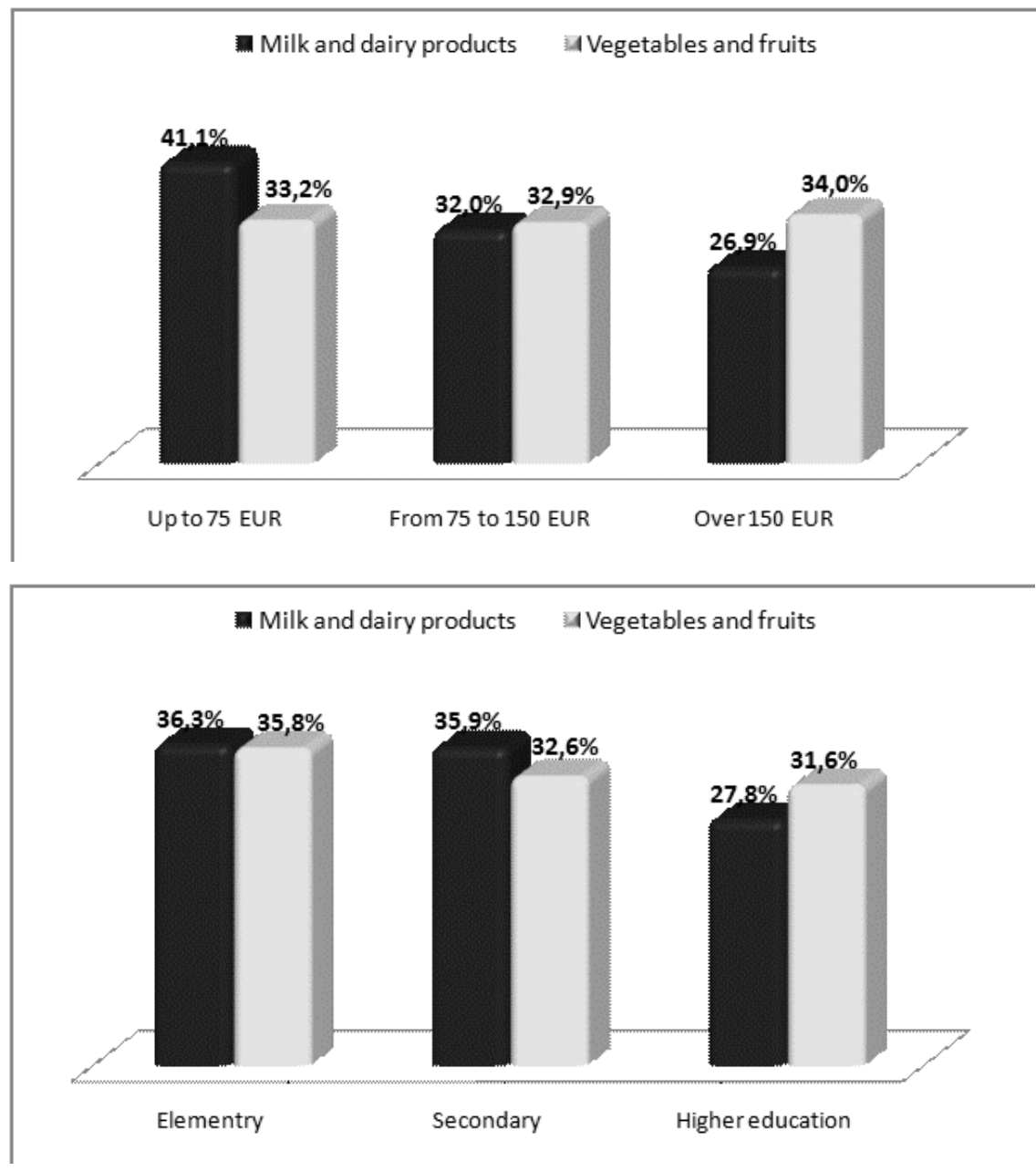

Fig. 3. Proportion (\%) of participants using less frequently consuming milk and dairy products by income in 2012.
Fig. 4. Proportion (\%) of participants less frequently consuming milk and dairy products by education in 2012 . 
from 15 countries were reviewed. These studies were mainly large-scale national dietary, household budget and health behaviour surveys. The meta-analysis showed that people belonging to higher social classes have healthier diets. Those with higher education, with the exception of inhabitants of the southern Europe, tended to consume more vegetables and fruit, and less fat. The socioeconomic differences in food consumption were not homogenous across Europe. The patterns varied by food groups and region.

Project results of food-related disparities observed in the present study were used in planning food and nutrition policy, programmes and dietary interventions aimed at promoting health among lower social classes and risk groups.

Clinical and epidemiology studies conducted over the past ten years in Republic of Macedonia have shown a reduced level of physical activity was found in $64.5 \%$ of the adult population and in $50 \%$ of girls aged from 7 to 12 years independent of educational level (Simovska, 2002). In the mentioned study conducted in the WHO European region (Currie et al., 2012) 31\% of participants were sedentary.

In accordance to UN Political Declaration on the Prevention and Control of Non-communicable Diseases (Anonymous, 2011), the Government should implement programmes that tackle the social determinants of NCDs with particular reference to the health in early childhood, the health of the poor, fair financing, and equitable access to primary health care services and essential medicines.
Also, governments should adopt the evidence-based global strategies developed by the WHO including the Global Strategy on Diet, Physical Activity and Health (Anonymous, 2004) and other programmes such as the Disease Control Priorities Project, as the foundation of future evidence-informed policies to reduce the burden of NCDs.

Various socioeconomic groups are differently affected by political and economics changes. Assessment of the trends in health and health behaviour of different socioeconomic groups in the Republic of Macedonia is essential for planning and evaluation of the NCDs prevention programme. Also, the research study provides results for health-policy decision-making and can be used for evaluating specific health promotion and NCDs prevention programmes. Changes in food content, guidelines and policy on food labelling and health claims, marketing, city planning that facilitates active transport (as opposed to motorised) are among the measures that will help to keep the NCDs epidemic under control. Projected future ratio of bread's economic status estimated using Buhlmann-Straub statistical method are presented in Table 1.

\section{ACKNOWLEDGMENTS}

The work was supported by the University Research Centre: "St. Clement of Ohrid", Bitola, in 2012. We extend our personal acknowledgment for their input to the whole team of the study including study coordinator, colleagues as well as to the students of "Study for Nutrition" who participated in the initial stage of the project.

ECONOMIC STATUS OF BREAD: PROJECTED FUTURE RATIO

(Standard Credibility Method: Buhlmann-Straub)

\begin{tabular}{|c|c|c|c|c|c|}
\hline $\begin{array}{c}\text { Number of participants } \\
\text { before } 2012 \\
\end{array}$ & $\begin{array}{c}\text { Economic status (income } \\
\text { per family member) }\end{array}$ & Actual excepted ratio & Credibility Factor Z & $\begin{array}{c}\text { Number of participants } \\
2012 \\
\end{array}$ & $\begin{array}{c}\text { Buhlmann empirical } \\
\text { Bayesian Estimate PFR }\end{array}$ \\
\hline \multicolumn{6}{|c|}{ White bread } \\
\hline 550 & Up to 75 EUR & $85.27 \%$ & 0.79 & 469 & $88.40 \%$ \\
\hline 502 & From 75 to 150 EUR & $96.02 \%$ & 0.78 & 482 & $96.89 \%$ \\
\hline 248 & Over 150 EUR & $92.74 \%$ & 0.64 & 230 & $95.36 \%$ \\
\hline Total 1300 & & & & Total 1181 & \\
\hline \multicolumn{6}{|c|}{ Semi White Bread } \\
\hline 138 & Up to 75 EUR & $105.07 \%$ & 0.65 & 145 & $103.28 \%$ \\
\hline 150 & From 75 to 150 EUR & $118.67 \%$ & 0.66 & 178 & $112.40 \%$ \\
\hline 63 & Over 150 EUR & $131.75 \%$ & 0.59 & 83 & $118.78 \%$ \\
\hline Total 351 & & & & Total 406 & \\
\hline \multicolumn{6}{|c|}{ Black Bread } \\
\hline 80 & Up to 75 EUR & $122.50 \%$ & 0.60 & 98 & $113.51 \%$ \\
\hline 184 & From 75 to 150 EUR & $100.00 \%$ & 0.70 & 184 & $100.00 \%$ \\
\hline 135 & Over 150 EUR & $112.59 \%$ & 0.60 & 152 & $107.60 \%$ \\
\hline Total 399 & & & & Total 434 & \\
\hline \multicolumn{6}{|c|}{ Whole grain bread } \\
\hline 11 & Up to 75 EUR & $145.45 \%$ & 0.38 & 16 & $117.08 \%$ \\
\hline 14 & From 75 to 150 EUR & $178.57 \%$ & 0.42 & 25 & $132.89 \%$ \\
\hline 15 & Over 150 EUR & $186.67 \%$ & 0.36 & 28 & $130.86 \%$ \\
\hline Total 40 & & & & Total 69 & \\
\hline
\end{tabular}




\section{REFERENCES}

Anonymous (1990). World Health Organization. Diet, Nutrition, and the Prevention of Chronic Diseases. Report of a WHO Study Group. Technical Report Series 797. Geneva: WHO, 1990. 203 pp.

Anonymous (1997). Education at the Glance: OECD Indicators. Paris: OECD.

Anonymous (2003). Annual Report for the "National Programme for Noncommunicable Disease Prevention and Control in Republic of Macedonia (WHO CINDI Programme). Ministry of Health of Republic of Macedonia and the WHO Country Office, 2003.

Anonymous (2004). WHO Global Strategy on Diet, Physical Activity and Health. http://www.who.int/dietphysicalactivity/strategy/eb11344/strategy_english_web.pdf (last accessed 11.05.2010).

Anonymous (2008). WHO. 2008-2013 Action plan for the Global Strategy for the prevention and control of NCDs, WHO, 2008. $42 \mathrm{pp}$.

http://www.who.int/nmh/Actionplan-PC-NCD-2008.pdf

Anonymous (2011). UN, Political declaration of the High-level Meeting of the General Assembly on the Prevention and Control of Non-communicable Diseases. Sixty-sixth session Agenda item 117 Follow-up to the outcome of the Millennium Summit, 2011.

http://ncdaction.org/page/the-solutions
Currie, C. et al. (eds.) (2012). Social determinants of health and well-being among young people. Health Behaviour in School-aged Children (HBSC) study: International report from the 2009/2010 survey. Copenhagen, WHO Regional Office for Europe, 2012 (Health Policy for Children and Adolescents, No. 6. http://www.euro.who.int/en/what-we-publish/abstracts/social-determinants-of-health-and-well-being-among-young-peopl e.-health-behaviour-in-school-aged-children-hbsc-study (last accessed 26 April 2012).

Martinovski, S. (2012). Geographic Information System (GIS) Modelling for Strategic Planning of Urban Environment Development. Unpublished doctoral thesis (PhD), University of Bitola "St. Clement of Ohrid", Faculty of Economy, Prilep.

Puska, P., Tuomilehto, J., Nissinen, A., Vartiainen, E. (eds.) (1995). The North Karelia Project. 20 Year Results and Experiences. Helsinki: National Public Health Institute. 363 pp.

Roos, G., Prattala, R. (1999). Disparities in Food Habits. Review of Research in 15 European Countries. Helsinki: National Public Health Institute.

Simovska V. (2002). Plan of action for integrated community and primary care based prevention and control of cardiovascular and other NCDs in FYR of Macedonia, 2002-2007. www.cindi.makedonija.com.

Simovska V. (2002). CINDI Health Monitor Survey-An integrated part of CINDI Conceptual Model in Macedonia.

http://www.cindi.makedonija.com/DOCS/CINDI_Health_Monitor_Survey_Macedonia_2002.pdf

18 September 2012

\section{ĒŠANAS PARADUMU UN FIZISKĀS AKTIVITĀTES LİMEN̦A MONITORINGS KĀ PAMATS JAUNAI NEINFEKCIJAS SLIMĪBU PROFILAKSES PROGRAMMAI MAĶEDONIJAS REPUBLIKĀ}

Pētījumā tika novērtēti 2012. gadā veikti ,,̌̌kērsgriezuma” pētījumi par ēšanas paradumu un fizisko aktivitāšu ietekmi uz neinfekcijas slimībām, no kurām galvenās ir sirds un asinsvadu slimības, 2. tipa diabēts, vēzis un hroniskas respiratorās slimības. Pētījums tika veikts piecos Maķedonijas republikas reǵionos un ietvēra 1600 respondentus vecumā no 10 līdz 64 gadiem. Tika izmantota aptaujas anketa par ēšanas paradumiem, kurā bija jautājumi par nedēḷas laikā patērētajām galvenajām produktu grupām. Pētījumā tika mērītas brīvā laika fiziskās aktivitātes. Pētījuma rezultāti parādīja, ka neinfekcijas slimību profilaksei, līdz ar fizisko aktivitāšu līmeṇa paaugstināšanu un èšanas paradumu main,u, ir jāfokusējas uz uztura sastāvu, ietverot pilngraudu maizes pieejamību, kā arī uz pārtikas etiķetēšanas politiku, veselīguma prasībām, mārketingu un pilsētu plānošanu, kas veicina aktīivu dzīvesveidu. 